\title{
Davranışsal İktisadın Çerçevesi: Teorik, Epistemolojik ve Metodolojik Bir Bakış'
}

\author{
Recep YÜCEDOĞRU (https://orcid.org/0000-0003-4798-9576), Department of Public Finance, Zonguldak \\ Bülent Ecevit University, Turkey; e-mail: recep.yucedogru@beun.edu.tr
}

Serenay DIRAZ (https://orcid.org/0000-0003-2361-3371), Department of Economics, Zonguldak Bülent Ecevit University, Turkey; e-mail: serenaydiraz@gmail.com

\section{The Framework of Behavioural Economics: A Theoretical, Epistemological and Methodological Overview ${ }^{2}$}

\begin{abstract}
Political economics commented on and drew inferences about certain psychological phenomena even before the marginalist revolution. As a result of the progress in natural sciences, economics started to test its theories by placing logical positivism and mathematics at the forefront. In doing so, they defined individuals as rational and pragmatist utopic agents. With the emergence of the cognitive revolution, advances in psychology made it possible to study the decision-making processes of individuals, which to a great extent led to the development of behavioural economics. In this study, the two phases of behavioural economics are discussed in retrospect, and then its epistemological and methodological backgrounds are investigated. Finally, relatively young Turkish literature on behavioural economics is systematically examined. This paper aims to provide a neat overview of behavioural economics in which researchers and interested parties might benefit in Turkey.
\end{abstract}

Keywords $\quad$ : Cognitive Biases, Heuristics, Behavioural Economics.

JEL Classification Codes : $\quad$ D91, E71.

\section{$\ddot{\mathbf{O z}}$}

Marjinal devrimden önce, politik iktisat olarak anılan iktisat bilimi, psikolojik olgular hakkında yorumlarda bulunmuştur. Doğa bilimlerinde yaşanan gelişmeler çerçevesinde, iktisat mantıksal pozitivizmi ve matematiği başat hale getirerek teorilerini test etmeye çalışmış, bireyleri rasyonel ve faydacı ütopik aktörler olarak tanımlamıştır. Bilişsel devrimle birlikte, psikoloji bireyin karar alma sürecini araştırmayı mümkün kılmış ve bu gelişme, davranışsal iktisadın doğuşunu beraberinde getirmiştir. Bu çalışmada davranışsal iktisadın iki aşaması tarihsel olarak tartışılmakta, ardından epistemolojik ve metodolojik arka planı irdelenmektedir. Nihayetinde, Türkiye'de yürütülen davranışsal iktisat araştırmaları değerlendirilmektedir. Çalışma, Türkiye'deki araştırmacılara ve kurumlara ve davranışsal iktisadın gelişimine katkı sağlamayı amaçlamaktadır.

Anahtar Sözcükler Bilişsel Önyargılar, Zihinsel Kısa Yollar, Davranışsal İktisat.

I Bu çalışma, Serenay Diraz'ın Zonguldak Bülent Ecevit Üniversites Sosyal Bilimler Enstitüsünde savunduğu "Ebeveyn Altruizminin Tasarruf Davranışları Üzerindeki Etkisi: Davranışsal İktisat Perspektifinde Bir Araştırma" başlıkl tezinden türetilmiştir.

2 This study is derived from Serenay Diraz's MA thesis titled "The Effect of Parental Altruism on Saving Behaviors: A Study in Behavioral Economics Perspective" which was defended at Zonguldak Bülent Ecevit University Social Sciences Institute. 


\section{Giriş}

İktisat disiplini, politik iktisat olarak anıldığı dönemlerde sosyolojik, kültürel, psikolojik olguları günümüze kıyasla daha fazla ele almıştır. Marjinal devrimle birlikte matematik ve fiziğin gelişimine paralel olarak doğa bilimlerine ve onların klasik döneminde elde ettiği kesinlik anlayışına öykünmüştür. $\mathrm{Bu}$ nedenle ana akım iktisat, matematiği neredeyse amaç haline getirmiş, teorilerini ekonometrik olarak ispatlayabilmek adına bireyleri rasyonel, her daim azami faydayı hedefleyen ütopik aktörler olarak tanımlamıştır (Erkan, 2016). Böylelikle ana akım iktisat teorilerinin sosyal gerçeklikten uzaklaştı̆̆ iddia edilmiştir. Bu noktada iktisat disiplininin ne yönde evrildiği tartışma konusu olmuş ve muhalif görüşler ortaya çıkmıştır. Böylece iktisatçılar ana akım iktisadı benimseyenler ve ana akım iktisadı eleştirerek heterodoks iktisadı savunanlar olarak iki gruba ayrılmıştır.

Davranışsal iktisat, bireylerin risk ve belirsizlik altında bilişsel önyargılar ve zihinsel kısa yollara maruz kalması sebebiyle rasyonel kararlar alamayacağını, bu sebepten psikolojik faktörlerin iktisat teorilerine dahil edilmesi gerektiğini ileri süren bir araştırma alanıdır. Bilişsel önyargılar, bireylerin rasyonel kararlardan sapmasına neden olan sistematik hatalardır. Bu hataların sebepleri nörolojik ve fizyolojik sinırlar (Schmid, 2004: 28), duygular, motivasyon eksikliği vb. olgular olabilir. Zihinsel kısa yollar ise, tercihlerin fazla olduğu ya da zaman kısıdının olduğu durumlarda bireylerin bilgiyi hızlı işleme eğilimine verilen addır. $\mathrm{Bu}$ işlem genellikle bireyin rasyonel karar alamamasına neden olmaktadır (Kahneman \& Tversky, 1974: 1124).

Davranışsal iktisat, erken dönem olarak nitelendirilen periyodunda ana akım iktisadın insanı ve insani özellikleri göz ardı eden, bireylerin geniş seçim skalasında her daim rasyonel karar alarak azami faydayı hedeflediği görüşüne eleştirel yaklaşmıştır ve bireylerin sınırlı rasyonel olduğunu savunmuştur. Yakın dönem davranışsal iktisat ise, bu varsayımları deneysel olarak irdeleyerek teorileri revize etmiştir.

Çalışmada ilk olarak davranışsal iktisat yaklaşımının teorik gelişimi tarihsel olarak incelenmiştir. Ardından davranışsal iktisadın epistemolojik arka planı Popper, Kuhn ve Lakatos'un görüşleri kapsamında tartışılmıştır. Davranışsal iktisadın epistemolojik olarak Popper ve Lakatos’a yakın olduğu sonucuna varılmıştır. Metodolojik çerçevede ise, davranışsal iktisat ve deneysel iktisat arasındaki farklılıklara değinilmiş, hipotetik seçim deneyleri ve gerçek çıktıyla yapılan deneyler irdelenmiş, deneylerin karşılaması gereken nitelikler açıklanmıştır. Son olarak Türkiye'de davranışsal iktisat üzerine yapılan ampirik çalışmalara yer verilmiştir.

\section{Davranışsal İktisat}

Ana akım iktisadın Homo economicus ${ }^{3}$ varsayımı, bireyleri rasyonel, sürekli azami faydayı hedefleyen, sınırsız hesaplama yeteneğine sahip aktörler olarak tanımlamaktadır

3 Richard Thaler, Homo economicus' $u$ Ekonlar ve Homo sapiens 'i Insanlar olarak nitelemektedir (bkz. Thaler \& Sunstein, 2013: 18). 
(Berg \& Gigerenzer, 2010: 134; Camerer \& Loewenstein, 2004: 3; Demir, 2013: 25). Bu durum ana akım iktisat teorilerinin geçerliliğinin sorgulanmasına sebep olmuştur. Davranışsal iktisat bireyleri Homo economicus olarak değil, Homo sapiens olarak ele almaktadır. Bireylerin nörolojik sınırlarını bilişsel psikolojik yöntemler aracılı̆̆ıyla ispatlayarak ana akım teorileri revize etmektedir.

Davranışsal iktisat, diğer iktisadi yaklaşımlar gibi politik bir çerçeveye sahip değildir (Tomer, 2007: 463). Davranışsal iktisada göre, bireylerin rasyonel davranamamasının sebebi, bireylerin davranış esnasında karşılaştığı bilişsel önyargılar ${ }^{4}$ (cognitive biases) ve zihinsel kısa yollardır (heuristics). Bireyler belirsizlik ve risk anlarında bu bilişsel önyargılara kapılarak sistematik hatalar yapmaktadır. Davranışsal iktisat, bahsi geçen bilişsel tuzakların etkilerini ana akım iktisat teorileri çerçevesinde asgariye indirmeye çalışarak teorilerin geçerliliğini arttırmayı amaçlamaktadır.

Bireylerin sistematik hatalarının sebepleri, beynin sınırlı derecede bilgi işleyebilmesi, öğrenebilir nitelikte olması ve duygusal ve sezgisel davranışlarda bulunabilmesi olarak sinıflandırılabilir (Schmid, 2004: 28). Kahneman (2003), bu sinıflandırmay1 1. Sistem ve 2. Sistem olarak ele almaktadır. 1. Sistem, duygusal, refleksif, kontrolsüz ve hızlıdır. 2. Sistem ise, değerlendirme ve hesaplama yapan, çabalayan ve 1 . Sisteme kıyasla daha yavaş karar veren bir yapıya sahiptir (Kahneman, 2011: 26-27). Karar alma mekanizmas1, devreye giren sistemin özelliklerine göre değişim gösterirken, bireyler bir yandan da bilişsel önyargıların ve zihinsel kısa yolların etkisiyle rasyonel karar alamamakta ve ana akım iktisadın Homo economicus varsayımını karşılayamamaktadırlar.

\section{Davranışsal İktisadın Tarihsel Gelişimi}

İktisat, tarih boyunca tüketimin ve üretimin olduğu her durumda var olmuştur. Politik iktisat olarak anıldığı dönemde filozofların görüşleriyle bilimsel olarak şekillenmiştir. Marjinal devrime kadar geçen süreçte, politik iktisat psikolojik, sosyolojik, kültürel, tarihsel yönleri çatısı altında barındırmış; marjinal devrimle birlikte iktisadın doğal bilimlere öykünme süreci başlamıştır. Bu süreçte Webergil rasyonalite varsayımı iktisadi düşünceye hâkim olmuş, bununla birlikte matematik araçtan ziyade amaç haline gelmiştir. İktisat teorilerinin matematiksel çerçeveyle ispatlanabilmesi için politik iktisatta ele alınan konular göz ardı edilmiş, bireyler Homo economicus varsayımı altında tekdüze ele alınmıştır. İktisadın mantıksal pozitivizmi başat hale getirmesi bazı iktisatçılar tarafından eleştirilse de bu, ana akım iktisadın hegemonyasına engel olamamıştır.

Davranışsal iktisadın tarihsel gelişimini ele alan çalışmalar genellikle ilk olarak Adam Smith'in Ahlaki Duygular Kuramı (The Theory of Moral Sentiments) kitabina referans vererek, kendisini davranışsal iktisatçı olarak addetmektedir (Camerer \& Loewenstein, 2004; Angner \& Loewenstein, 2006; Laibson \& List, 2015; Nava vd., 2015). Bu çalışmada

4 Ek 1'de bilişsel önyargıların tümü zihin ă̆ (codex) şeklinde gösterilmiştir. 
ise 14. yüzyı1 İslam düşünürlerinden İbn Haldun davranışsal iktisatçı olarak ele alınırken, tarihsel açıdan Adam Smith'ten önce gelmektedir.

İbn Haldun tarafından kaleme alınan Mukaddime ${ }^{5}$ sosyal bilimleri disiplinler aras1 değerlendiren ilk çalışma olarak kabul edilmektedir (Boulakia, 1971: 1106). Mukaddime'de toplumsal etkileşimler asabiyyet kavramıyla açıklanmaktadır. Asabiyyet, grup içi bireylerin grubun refahını sağlamak adına azami çabayı gösterme isteğidir (Kozak, 1984: 119). İş birlikçi insan davranışları, asabiyyet kavramına göre toplumsal bir temele dayanmaktadır (Gierer, 2001: 91). İbn Haldun yaşadığ dönemde insanların içinde bulundukları toplulukların refahını artırabilmek için altruistik davranışlarda bulunduklarından bahsetmiştir. Göçebe topluluklarda bu durum akrabalıkla ilişkili olabilir (Kayapınar, 2006: 89). Yerleşik toplumlar ise devlet kurulurken iş birliği içinde hareket ederken, gelişim ve kalkınma aşamasında halk, yönetimler ve hükümdarlıklar arasındaki mesafe gittikçe artmakta ve mesafe arttıkça gelişim yavaşlamaktadır. İbn Haldun'a göre bunun sebebi halka yönelik uygulanan yaptırımlardır (İbn Haldun, 2013: 265).

İbn Haldun'un bir diğer çıkarımı ise bireylerin bir öz benliğe sahip olmasıdır. Dünyaya gelindiği anda toplumsal ve çevresel faktörlerden etkilenen öz benlik, bireyin kişiliğinin oluşmasına; iyiye veya kötüye yönelmesine sebep olur (İbn Haldun, 2013: 259). İyi bireyler iktisadi gelişmenin bir etkenidir (Kozak, 1984: 143). Yerleşik toplumlar iş birliği ve iş bölümüyle birlik içerisinde gelişim sağlarken, birliklerini sürdürebilmeleri için bir lidere; bir yönlendiriciye ihtiyaç duyarlar (Boulakia, 1971: 1107; İbn Haldun, 2013: 124). Bu görüş, paternalizmle ${ }^{6}$ benzer niteliklere sahiptir. Davranışsal iktisat ise dürtme adı altında geliştirdiği politikalarla paternalizmi desteklemektedir (Camerer vd., 2003: 1211).

Haldun'un ayrıca, Mukaddime'de tarih aktarıcılığının önemine atıfta bulunurken bazı bilişsel önyargıları da tespit ettiği söylenebilir. Haber aktaranların haberi yanlış anlama, yanlış değerlendirme ve abartma gibi özelliklerine değinirken; haberi alan bireyin, aktaran kişiye duyduğu güvenden ötürü haberin gerçekliğini sorgulamama gibi eğilimlerine dikkat çekmektedir (İbn Haldun, 2013: 97-103).

\section{Adam Smith (1759), Ahlaki Duygular Kuramı (The Theory of Moral Sentiments)} kitabında davranışsal iktisatta hala geçerliliğini koruyan bazı psikolojik içgörüleri ele almaktadır. Bunlardan ilki sempati ilkesidir. Bireyler sempati yöntemiyle başkalarının duygularını değerlendirir ve bu değerlendirme sonucunda acı hissi mutluluğa kıyasla daha yoğun hissedilir. Kahneman ve Tversky'nin kayıptan kaçınma önyargısı bu durumla benzer niteliktedir (Camerer \& Loewenstein, 2004: 5). Bir diğer içgörü ise Smith'in iki benlik görüşüdür. Bireylerin karar alma mekanizması iki benliğe tabidir. İlk benlik, davranışı planlayan ve sonuçlarını değerlendiren; ikinci benlik ise gerçekleştiren ve sonuçları

\footnotetext{
5 İbn Haldun'un kısa adı Kitabu'l-iber olan kitabına giriş niteliğinde yazılan Mukaddime, tarih kitabı olarak ele alınsa da iktisat, sosyoloji ve siyaset gibi konuları da içeren ilk eserlerden biri olarak tanımlanmaktadır (Kozak, 1984: 17).

6 Paternalizmle ilgili detaylı tartısma için bkz. Hershey, 1985; Acquisti, 2009.
} 
deneyimleyen olarak tanımlanmaktadır (Smith, 2018: 169). Bu görüş daha sonraları Shefrin ve Thaler (1988) ve Kahneman (2003) tarafindan da ele alınmaktadır.

Jeremy Bentham (1781) ise, psikolojik ögeleri fayda açısından ele almıştır. Bentham'ın fayda ilkesi, mutluluk veren davranışların arttırılması; acı, keder, hüzün veren davranışların azaltılması gerektiğini savunarak azami faydaya ulaşmayı amaçlamaktadır (Bentham, 1781: 14). Bentham her ne kadar psikolojik yönleri ele alsa da temelde bireyleri hedonist (hazcı) olarak tanımlamıştır. Ana akımcılar ise bu görüşü rasyonaliteyle bağdaştırmış, rasyonel insanların hedonist olduğu görüşünü ele almıştır (Dumludağ \& Ruben, 2015: 6).

Ana akımcılar, Bentham'da olduğu gibi Edgeworth ve Fisher'da da psikolojik değerlendirmeleri matematiksel amaca ulaşabilmek adına elimine etmişlerdir (Thaler, 1997: 441). Edgeworth (1881), faydanın temelinde ego ve çıkarların çatıştığı görüşünü ileri sürmüş fakat bireyleri hedonist olarak tanımlamaya devam etmiştir (Edgeworth, 1881: 56). Fisher (1928) ise bireylerin nominal ve reel fiyatlar arasındaki ayrımı fark etmediği durumu para yanılsaması olarak adlandırmıştır. Bu tespitiyle Kahneman ve Tversky'nin bilişsel önyargılar üzerindeki bulgularını öngörmüştür (Thaler, 1997: 440). Ardından Fisher (1930), Faiz Teorisi kitabında tüketim tercihlerini iki zaman ve iki malın olduğu bir piyasada irdelemiş; bireylerin bugünkü tüketimlerinin faydasını gelecekteki tüketimlerinden daha fazla değerlendirdiğini ileri sürmüştür. Fisher'a göre bugünkü tüketimini tercih eden bireyler, gelecek için çözüm üretebilme ihtimali ve gerekli tüketimin gerçekleştirilmesi açısından kısmi rasyonel, geleceği şansa bırakma açısından ise kısmi irrasyoneldir. Thaler (1997), bu tespitlerinden ötürü Fisher’1 modern davranışsal iktisatçı olarak anmıştır.

Keynes (1921) ise rasyonaliteyi olasılıkla ilişkilendirmiştir. Keynes’e göre bireyler rasyonel ve irrasyonel davranabilir, bu ihtimal nesneldir ve mantıklıdır. Böylelikle belirsizliğin olmadığ 1 durumlarda bireyler rasyonel davranabilir. Ardından Keynes (1997) Genel Teori' de bireyleri sübjektif olarak ele almış ve her bireyin davranışlarının temelindeki motivasyonun ayrıştığını ileri sürmüştür. Bu motivasyonları ise hayvansal güdüler ${ }^{7}$ olarak adlandırmıştır.

O dönemlerde Homo economicus varsayımına yöneltilen eleştiriler her ne kadar yoğun olsa da psikolojinin görgül değerlendirmelere tabi olması bu eleştirilerin önemsenmemesine sebep olmuştur. Bilişsel devrime kadar geçen süreçte ana akım iktisat teorileri geçerliliğini korurken, bilişsel devrimle birlikte bilimsel anlamda gelişim gösteren psikoloji disiplini ana akım iktisada yöneltilen eleştirilerin temelini doldurmaya başlamıştır.

\subsection{Erken Dönem Davranışsal İktisat}

Herbert Simon ve George Katona'nın ön planda olduğu erken dönem davranışsal iktisat dört farklı okulda aynı zamanda gelişim göstermeye başlamıştır. Bu okullar

Keynes (1997: 108) hayvansal güdüleri öngörü, hesaplama, girişim, para hırsl, gurur, önlem alma, gelişme, bağımsızlık olarak tanımlamaktadır. 
Katona'nın bulunduğu Michigan ekolü, Simon'ın bulunduğu Carnegie-Mellon ekolü, Oxford ve Stirling ekolleri olarak suralanabilir (Angner \& Loewenstein, 2006: 20). Erken dönem davranışsal iktisadın oluşumundaki en önemli etken bilişsel devrimdir. Bilişsel devrimin $^{8}$ meydana getirdiği disiplinler arası çalışma alanları davranış yapısının çözümlenmesi üzerine odaklanmıştır.

Disiplinler arası çalışmalarıyla bilinen Herbert Simon, psikolojinin sosyal bilimlere dâhil edilmemesi eksikliğini eleştirmiş, doktora tezinde kamu yönetimindeki psikolojik etkenleri irdelemiştir. Simon (1966)'a göre bireyler rasyonel davranışlarda bulunmazlar, davranışları refleksif olabilir. Bireylerin karar mekanizması geniş seçim skalasında, seçimlerinin sonuçlarını değerlendirebilecek ve rasyonel tercihte bulunabilecek kadar nitelikli değildir (Simon, 1966: 80-81). Tüm bu koşulların sağlanabilmesi için bilgi eksikliğinin olmaması ve bireylerin tecrübe etmedikleri olaylar için bile en etkin seçimi yapabilmesi gerekmektedir.

Klasik rasyonel seçim teorisine göre bireyler tam bilgi varsayımı altında karar almakta, azami getiriyi elde edeceği ve fırsat maliyetini asgariye indireceği seçimi yapmaktadır. İkincisi, bireyler davranışlarının sonuçlarını etkin şekilde tahmin edebilmektedir. Son olarak ise bireyler her daim en iyi seçimi tercih etmektedir (Simon, 1955: 103). Simon (1955) bu varsayımların geçerli olmadığını bireylerin kısıtlı hesaplama kabiliyetiyle açıklayarak, bireyleri sınırlı rasyonel olarak tanımlamaktadır.

Simon'ın sınırlı rasyonalite varsayımı, Muth'un klasik rasyonel seçim teorisine beklentileri dâhil ederek rasyonel beklentiler teorisini ortaya atmasıyla geri planda kalsa da günümüzde davranışsal iktisadın en temel varsayımlarından biri olarak kabul edilmektedir.

Aynı dönemde George Katona da Michigan Üniversitesi’nde tüketici tercihlerindeki psikolojik etkenleri çözümleme üzerine araştırmalar yapıyordu. Michigan Üniversitesi Sosyal Araştırmalar Enstitüsü bünyesinde bulunan Tüketici Araştırma Merkezi'nin başında olan Katona, Amerikan hanehalkının 2. Dünya Savaşı sırasında enflasyona yönelik davranışlarını ve tasarruflarını tespit edebilmek adına uzun yıllar sürecek bir anket programı uyguladı (Juster, 2004: 120). Ankete tüketim davranışlarını ve enflasyon beklentisini çözümleyecek birkaç açık uçlu soru eklendi (Katona, 1951: 64). 1940-1970 arası anketler uygulanmaya devam edildi ve sonucunda tüketim davranışlarındaki değişim üzerine bir veri seti elde edilmiş oldu (Curtin, 1982: 341). Katona, bireylerin tutum ve davranışlarını, beklentilerini, isteklerini teoriye dahil etmeye çabalasa da (Warneryd, 1982: 4) anket çalışmasının bunun için yeterli olmayacağını; bu sebepten psikolojik deneylerin iktisadi davranışları tespit etmede kullanılması gerektiğini savunmuştur (Katona, 1951: 301-303). Psikoloji ve iktisat iş birliğini davranışsal iktisat olarak terminolojiye kazandıran Katona,

8 Bilişsel devrimin gerçekleşmesine sebep olan etkinliğin Hixon Sempozyumu olduğu düşünülmektedir. "Beyin Mekanizması ve Davranış" konulu sempozyum farklı alanlardaki bilim insanlarını bir araya getirerek disiplinler arası bir görüş alışverişsi yaratmıştır (Gardner, 1985: 10-35). 
makro düzeyde gerçekçi sonuçlar elde edilebilmesi için ilk olarak rasyonel varsayılan bireylerin davranışlarının çözümlenmesi gerektiğini belirtmiştir (Katona, 1951: 63).

Katona'nın makro-mikro düzeyler üzerindeki yorumlarına benzer görüşleri Harvey Leibenstein ve Tibor Scitovsky de savunmaktadır. Leibenstein (1966), pareto etkinliği (X etkinliği) teorisini X-Etkinsizliği olarak revize etmiştir. Pareto etkinliği, tüketici faydası, azami firma kârı ve asgari maliyetin dengelendiği durumda oluşur (Çetin, 2010: 185). Leibenstein, firmalar yerine bireyleri en küçük karar alma birimleri olarak değerlendirmiş ve etkinsizliğin sebeplerinin bireylerin davranışları olduğunu ileri sürmüştür (Leibenstein, 1966: 413). Scitovsky (1976) ise, bireylerin rasyonel varsayılmasının bilimsel etiğe aykırı olduğunu ve bilişsel deneylerin iktisada uygulanması gerektiğini savunmuştur (Scitovsky, 1976: xii-xiii).

Michigan'da Katona, Carnegie-Mellon'da Simon'ın katkılarıyla şekillenen erken dönem davranışsal iktisat, o dönemde Oxford'da koordinasyon ve belirsizlik ve Stirling Üniversitesi'nde eklektisizm, problem çözme ve bilgi işleme üzerine yapılan çalışmalarla gelişim göstermiştir (Earl, 2005: 5). Erken dönem davranışsal iktisadın ana akım iktisada yaklaşımı her ne kadar yakın dönemin yaklaşımından farklı olsa da erken dönemde ele alınan konular yakın dönemin temelini oluşturmuştur.

\subsection{Yakın Dönem Davranışsal İktisat}

1970'lerde Kahneman ve Tversky’nin bilişsel psikolojiyle bireylerin davranışlarını aydınlatması ve bu davranışları iktisadi teorilere dâhil etmesiyle başlayan yakın dönem davranışsal iktisat günümüzde geçerliliğini korumaktadır.

Tversky ve Kahneman, 1971-1973 yılları arasında Oregon Araştırma Enstitüsü'nde bilişsel önyargılar ve zihinsel kısa yolları araştırmışlardır (Tversky \& Kahneman 1971, 1973; Kahneman \& Tversky 1972, 1973). Bireyler bir davranışta bulunurken, mevcut bilgiyi hızlıca işleme eğilimine sahiptirler. Böylelikle yanlış değerlendirmeler yapabilmektedirler (Tversky \& Kahneman, 1974: 1124). Kahneman ve Tversky zihinsel kısa yolları farklı demografik özelliklere sahip katılımcılarla test etmiş ve etkinin her bireyde geçerli olabileceğini ispatlamışlardır (Tversky \& Kahneman, 1971; Kahneman \& Tversky, 1972).

Tversky ve Kahneman (1971), ilk olarak Bayesçi olasılık teoreminin Büyük Sayılar Kanunu'nu araştırmalarına konu edinmişlerdir. Büyük Sayılar Kanunu'na göre, bir çıkarımla alakalı örneklem ne kadar geniş olursa, çıkarım gerçeğe o kadar yakın olmaktadır. Tversky ve Kahneman, bireylerin karar alırken bu bilgiyi değerlendirmediklerini ortaya koymuş, bu yanılgıya ise Küçük Sayılar Kanunu adını vermişlerdir (Tversky \& Kahneman, 1971: 106). Öte yandan bireyler, şans faktörünü adil olarak değerlendirme eğilimine sahiptirler. Bireyler yazı-tura oyununda arka arkaya 5 kere yazı elde ettiklerinde 6 . atışın tura geleceğini düşünerek \%50'lik ihtimali göz ardı ederler; bu durum kumarcının yanılgısı olarak tanımlanmaktadır. (Kahneman \& Tversky, 1971: 105-106). Küçük Sayılar Kanunu ve kumarcının yanılgısı, temsililik (representativeness) zihinsel kisa yolunun alt 
başlıklarıdır. Temsililik, grup içerisindeki bir bireyin özelliklerinin tüm grup üyelerinin özelliklerini temsil etmesi örneğiyle açıklanabilir (Tversky \& Kahneman, 1974: 1124).

Bireyler belirsizliğin olduğu durumlarda karar almaya çalışırlarken, mevcut bilgilerini değerlendirerek tahminde bulunurlar. Mevcut bilgiler üzerinden tahmin etme eğilimi mevcudiyet (availability) zihinsel kısa yolu olarak tanımlanmaktadır (Tversky \& Kahneman, 1973: 208). Bu duruma, Türkiye'de Ayşe ismine sahip kaç kişi vardır sorusuna bireylerin çevresindeki Ayşeleri düşünerek bir tahminde bulunması örnek verilebilir.

Tversky ve Kahneman (1974), yaptıkları deneyde 0-100 aralığında hileli bir çark kullanmış ve katılımcıların bir kısmının 10, bir kısmının ise 60 değerini elde etmesini sağlamışlardır. Ardından katılımcılara kaç Afrika ülkesi BM'ye üyedir sorusu yöneltilmiş, 10 değerini elde eden katılımcıların verdiği cevap ortalama 25 olurken; 60 değerini elde eden katılımcıların ortalama tahmini 45 olmuştur (Tversky \& Kahneman, 1974: 1128). Bu durum, ayarlama ve çapalama zihinsel kısa yolu olarak literatürde yer edinmektedir. Bireyler, herhangi bir veriyi kullanarak tahminlerine ayarlama yaparlar ve bu ayarlama yapilırken çapalama etkisine maruz kalırlar (Kahneman \& Tversky, 1974: 1128).

Bireyler karar alırken bir çerçeveye göre tercihte bulunurlar. Çerçeveler bireylerin özelliklerini, görüşlerini ve alışkanlıklarını yansıtır. Çerçeveleme etkisi, risk ve belirsizlik altında, bireylerin karar alma sürecinde maruz kaldığı bilişsel süreç olarak tanımlanabilir. $\mathrm{Bu}$ süreçte birey çeşitli içsel uyaranların etkisinde kalarak, yani kararları çerçevelenerek tercihte bulunabilir. Ana akım iktisadın rasyonalite varsayımı ele alındığında bireylerin davranışlarının çerçeveleme etkisiyle değişmemesi gerekir. Tversky ve Kahneman (1981), bu durumun aksini ispatlamış ve bireylerin rasyonel olmadığını bir kez daha yaptıkları deneyle bulgulamışlardır. Deneyde katılımcılara bir salgın durumunda (Asian Disease) 600 kişinin ölme ihtimali olduğu bir seçim problemi yöneltilmiştir. İlk gruba 200 kişinin kurtulacağı ya da $1 / 3$ oranında 600 kişinin kurtulamayacağı durumda hangisini tercih edecekleri sorulmuş ve katılımcılar riskten kaçınarak 200 kişinin kurtulmasını tercih etmişlerdir. İkinci gruba ise 400 kişinin kurtulamayacağı ya da 1/3 ihtimalle herkesin kurtulacağı, 2/3 ihtimalle ise 600 kişinin kurtulamayacağı seçimi yöneltilmiş ve katılımcılar riskli kararı tercih etmişlerdir. Temelde iki soru da istatistiksel olarak aynıdır ve rasyonalite varsayımına göre her iki problemin yanıtı aynı olmalıdır. Deneyde çerçeveleme etkisinin karar mekanizması üzerinde yarattığı keskin etki gözler önüne serilmiştir (Tversky \& Kahneman, 1981: 453).

Risk ve belirsizlik altında gerçekleştirilen davranışların zihinsel kısa yollar aracılığıyla farklılaştığı gözlemlenmiş, bu noktada bireylerin faydayı nasıl değerlendirdiği sorusu akıllarda canlanmıştır. Kahneman ve Tversky (1979), Bernoulli'nin beklenen fayda teorisini revize etmiştir (Loewenstein, 2000: 426). Beklenen fayda teorisinde 3 varsayım mevcuttur. Bunlar; varlık durumu, beklenti ve riskten kaçınmadır. Beklenti ve varlık durumu temelde birlikte değerlendirilebilir. Birey, davranış öncesi ve sonrasını değerlendirir ve varlık durumunda bir iyileşme bekliyorsa davranışını gerçekleştirir. Eğer varlık 
durumlarında bir değişim gözlemlenmezse ya da mevcut durumdan daha kötü bir sonuç elde edilebilecekse riskten kaçınırlar (Kahneman \& Tversky, 1979: 263-264).

Beklenen fayda teorisinde bireyler rasyonel varsayıldığı için her daim doğru kararlar alırlar ve azami faydaya ulaşırlar. Kahneman ve Tversky (1979), çalışmalarında hipotetik bir seçim deneyi gerçekleştirmiştir. Bireylere ilk olarak \%33 olasılıkla \$2500, \%66 olasılıkla $\$ 2400$ elde edecekleri ve \%1 olasılıkla bir kazanç elde etmeyecekleri paket ve $\$ 2400$ kazanmalarının garanti olduğu bir paket sunulmuş; bireylerin \%82'si garanti olan \$2400'1 almayı tercih etmişlerdir. Beklenen fayda teorisine göre ilk seçimin faydası daha yüksektir $(2500 * 0.33+2400 * 0.66>2400)$. Bireyler, ana akım iktisadın varsaydığı gibi rasyonel olsalardı, ilk paketi tercih ederler ve risk alırlardı. Fakat bireyler sınırlı hesaplama kabiliyetine ve zihinsel kısa yollara sahiptir, bu sebepten rasyonel değillerdir (Kahneman \& Tversky, 1979: 265).

Kahneman ve Tversky, beklenen fayda teorisini bilişsel önyargılar ve zihinsel kısa yollar temelinde beklenti teorisi olarak revize etmişlerdir. Beklenti teorisinde davranış gerçekleşmeden önce bireyler iki aşamadan geçmektedirler. İlk olarak, bireyler seçimlerini gerçekleştirmek için verileri kullanarak hesaplama ve düzenleme aşamasından geçerler, yani ön değerlendirme yaparlar. İkinci olarak, düzenlenen seçimler üzerine bir değerlendirmede bulunurlar. Bu aşamada bireyler bir referans noktası belirleyerek kazançlarını ve kayıplarını değerlendirirler (Kahneman \& Tversky, 1979: 274-278).

Bireyler, farklı risk koşullarında kazançlarını ve kayıplarını farklı değerlendirirler. Ana akım fayda teorisine göre $100 \mathrm{TL}$ ve $200 \mathrm{TL}$ arasındaki artışla $1100 \mathrm{TL}$ ve $1200 \mathrm{TL}$ arasındaki artışın faydası eşit olmaktadır. Fakat bireylerin referans noktalarına göre bu kazancı ağırlıklandırmaları farklılaşır. 100 TL'den 200 TL'ye yönelik gerçekleşen artış bireyleri daha fazla mutlu etmektedir. Bu durumda kazanç fonksiyonu dışbükeydir. Tersi düşünüldüğünde ise, bireyler 200 TL'den 100 TL'ye doğru bir düşüş yaşadıklarında, 1200 TL'den 1100 TL'ye gerçekleşecek düşüşten daha fazla üzüntü hissederler. Bu durumda kayıp fonksiyonu içbükeydir (Kahneman \& Tversky, 1979: 278). Kayıplar, mevcut durumdaki refahın düşmesine sebep olacağından, kayıpların ağırlıklandırılması kazançlardan daha yoğun olmaktadır (Kahneman \& Tversky, 1979: 280).

Özetle, beklenti teorisinin değer fonksiyonu; referans noktasını içermeli, kazançlar ve kayıplar için azalan verimlere tabi olmalı ve kayıpların ağırlıklandırılması daha baskın olduğundan, kayıp fonksiyonu kazanç fonksiyonuna oranla daha dik konumda olmalıdır (Kahneman \& Tversky, 1979: 279). 


\section{Grafik: 1}

\section{Değer Fonksiyonu}

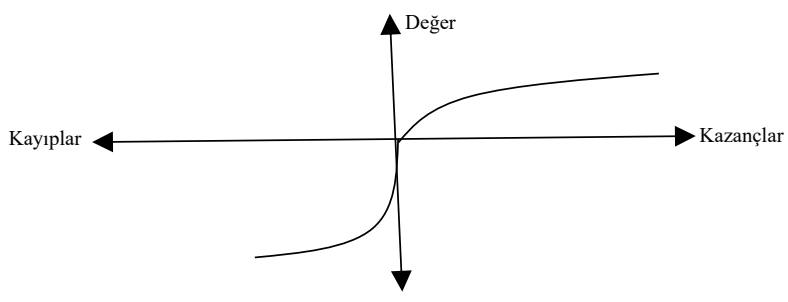

Kaynak: Kahneman \& Tversky, 1979.

Kahneman ve Tversky'nin çalışmaları, özellikle beklenti teorisi, bilişsel psikolojik deneylerin iktisat disiplinine uygulanmasına ön ayak olarak, gelecekte davranışsal iktisada yönelik gerçekleşecek araştırmalara referans olmuştur.

Kahneman ve Tversky'nin referans olduğu, modern davranışsal iktisadın kurucularından olan Richard Thaler, 1974 yılında doktora tezinde işçi ücretleri ve kaza sonucu gerçekleşen iş̧i ölüm oranlarını Sherwin Rosen danışmanlığında ana akım perspektiften karşılaştırmışırı (Thaler \& Rosen, 1976: 32). Doktora tezi için araştırmalar yaparken, ana akım paradigmanın rasyonalite varsayımına aykırı durumlar tespit etmiş ve 1980'li yıllarda Journal of Economic Perspectives'te bu tespitlerini meslektaşlarıly birlikte masaya yatıran, 19 makaleden oluşan Anomaliler serisini yayımlamıştır. Thaler bu çalışmaları sırasında daha sonraları donanım etkisi (endowment effect) olarak adlandırılacak olan anomaliyi tespit etmiştir; fakat bunu ispatlayacak analizin ne olduğu konusunda bir fikre sahip değildir (Thaler, 2015: 15).

Thaler, Stanford'da 1976 yılında düzenlenen bir konferansa danışmanı Rosen ile katılmış, orada karar alma mekanizması üzerine çalışmalar sürdüren Baruch Fischhoff'la fikir alışverişinde bulunmuştur. Fischhoff, analiz yöntemini belirleyebilmesi adına Thaler'a Paul Slovic, Kahneman ve Tversky'nin çalışmalarını önermiştir (Barberis, 2018: 12; Angner \& Loewenstien, 2006: 32). Ardından Thaler, Kahneman ve Tversky'nin beklenti teorisi ışığında donanım etkisini araştırmış; bu durumu bireylerin sahip olduklarını sahip olmadıklarından daha fazla ağırlıklandırması olarak tanımlamıştır. Kahneman vd. (1990) tarafından donanım etkisi üzerine çeşitli örneklemlerle deneyler gerçekleştirilmiştir. Bu deneylerin en popüleri kahve kupası deneyi olmuştur. Deneyde ilk olarak, bir grup katılımcıya kupa hediye edilmiş ve kupayı satmak için listeden bir fiyat belirlenmesi istenmiştir. Farklı bir "gruptan" ise aynı kupayı satın almak bir fiyat belirlemeleri istenmiştir. Araştırmaların sonucunda kupaya sahip katılımcıların, kupaya sahip olmayanlara oranla 2 kat daha fazla değer biçtikleri kanıtlanmıştır. Bu durum, statüko önyargısı ve kayıptan kaçınma ilkesiyle ilişkilendirilebilir (Kahneman vd. 1991:194).

Kayıptan kaçınma ilkesi, çoğu önyargının temelinde yer almaktadır. Thaler'ın keşfettiği batık maliyet (sunk cost) önyargısı da kayıptan kaçınma ile açıklanabilir. Batık 
maliyet önyargısına göre bireyler kazançlarını zevkle, kayıplarını acıyla değerlendirirler. Bu durumda acı veren davranışlardan kaçınırlar. Thaler batık maliyet önyargısını, bireylerin para vererek elde ettikleri şeyleri kaybetmelerini, çaba harcamadan elde ettikleri şeyleri kaybetmeye oranla daha fazla ağırlıklandırması olarak tanımlamıştır (Thaler, 1980: 49).

Shefrin ve Thaler (1988), bireylerin tasarruf davranışını etkileyen üç farklı önyargı tespit etmiştir. Bunlardan biri Kahneman ve Tversky’nin çerçeveleme etkisi, diğerleri ise otokontrol ve zihinsel hesaplamadır. Otokontrol önyargısına göre bireyler iki benliğe sahiptir. Bu benlikler planlayıcı ve yapıcı olarak tanımlanmıştır. Planlayıcı gelecekteki davranışa karar veren, davranış sonucunda oluşabilecek fayda ve zararı değerlendiren; yapıcı ise bu davranışları gerçekleştiren ve sonuçlarını yaşayan benlik olarak nitelendirilmektedir. Yapıcı miyoptur, yalnızca o anın faydasını düşünür ve ona göre davranışlarını gerçekleştirir. Tasarruf açısından ele alındığında, yapıcı, tüketim aracılığıyla faydasını azami düzeye çıkarma eğilimindedir (Shefrin \& Thaler, 1988). Zihinsel hesaplama ise, bireylerin hızlı hesaplama yapabilmesi adına tercihlerini sınıflandırarak değerlendirmesi olarak tanımlanmaktadır. Thaler (1980) bu önyargıyı farklı çalışmalarında da ele almış ve durumu işlem faydasıyla ilişkilendirmiştir. Thaler (1980), işlem faydasını beklenti teorisinin değer fonksiyonu temelinde değerlendirmiş, fakat bunu iki farklı işlem -birleşim ve ayrışımdâhilinde incelemiştir. İki işlemden de fayda elde edildiğinde bireyler bu durumu ayrışım işlemiyle; iki işlemden de zarar elde edildiğinde bu durumu birleşim işlemiyle değerlendirmektedir. Bir işlemin faydası diğer işlemin zararından fazla ise, bu durum birleşim işlemine tabi olmalıdır, fakat beklenti teorisinde kayıplar kazançlara oranla daha dik seyrettiğinden, bu varsayım ele alınmamaktadır. Bir işlemin zararının faydasından büyük olduğu durumlarda ise, farkın yüksek olduğu durumlarda ayrışım, düşük olduğu durumlarda ise birleşim işlemi uygulanmaktadır.

Thaler'a göre, zihinsel hesaplama yapılırken bir mal ve hizmet için yapılan değerlendirme birbirinden farklılaşmaktadır. Bu durumda, ana akım iktisadın ikame edilebilirlik (fungibility) ${ }^{9}$ varsayımı geçerliliğini yitirmektedir (Thaler, 1999: 193). Hastings ve Shapiro (2018), Thaler'ın bu fikrini destekleyen bulgulara ulaşmışlardır. Çalışmada, imkânı olmayanlara yapılan gıda yardımlarının bireyler tarafindan yalnızca gıda için kullanıldığg, gıda harcamalarından artan değerin ise gelecekte tekrar gida temin edebilmek için ayrıldığı sonucuna ulaşmışlardır.

Thaler'ın davranışsal iktisada en büyük katkısı "dürtme” olarak nitelendirilebilir. Thaler dürtme uygulamalarıyla, bilişsel önyargıların yarattığı sapmaları asgari düzeye indirgemiş ve davranışsal iktisadın bulgularının politika aracı olarak değerlendirilmesine olanak sağlamıştır. Dürtme kavramı, iktisattan hukuka, çevre politikalarından sağlık sektörüne kadar geniş bir yelpazede uygulanmaya başlanmıştır. Hükümetler daha etkin politikalar uygulayabilmek adına davranışsal içgörü (behavioral insights) takımları kurmuş ve davranışsal iktisadın etki alanı genişlemiştir (Thaler \& Sunstein, 2015).

\footnotetext{
9 İkame edilebilirlik varsayımına göre, aynı değere sahip iki mal birbiri yerine kullanılabilir.
} 
Dürtme adına verilebilecek en güzel örneklerden biri, Thaler ve Benartzi (2004)'nin tasarladığı SMarT programıdır. Bireylerin yeterli tasarruf düzeyine ulaşamama sebeplerini bilişsel önyargılar kapsamında değerlendiren Thaler ve Benartzi, bireylerin statüko önyargısı, kayıptan kaçınma, çerçeveleme gibi etkiler dolayısıyla tasarruf etmediklerini bulgulamış, programa otomatik katılım sağlanması ve tasarruf oranındaki artışın maaş artı̧ıyla ilişkilendirilmesiyle bu önyargıların etkileri aşılmıştır.

Grafik: 2

\section{Otomatik Katılım ve Otomatik Tasarruf Oranı Artıșı (\%)}

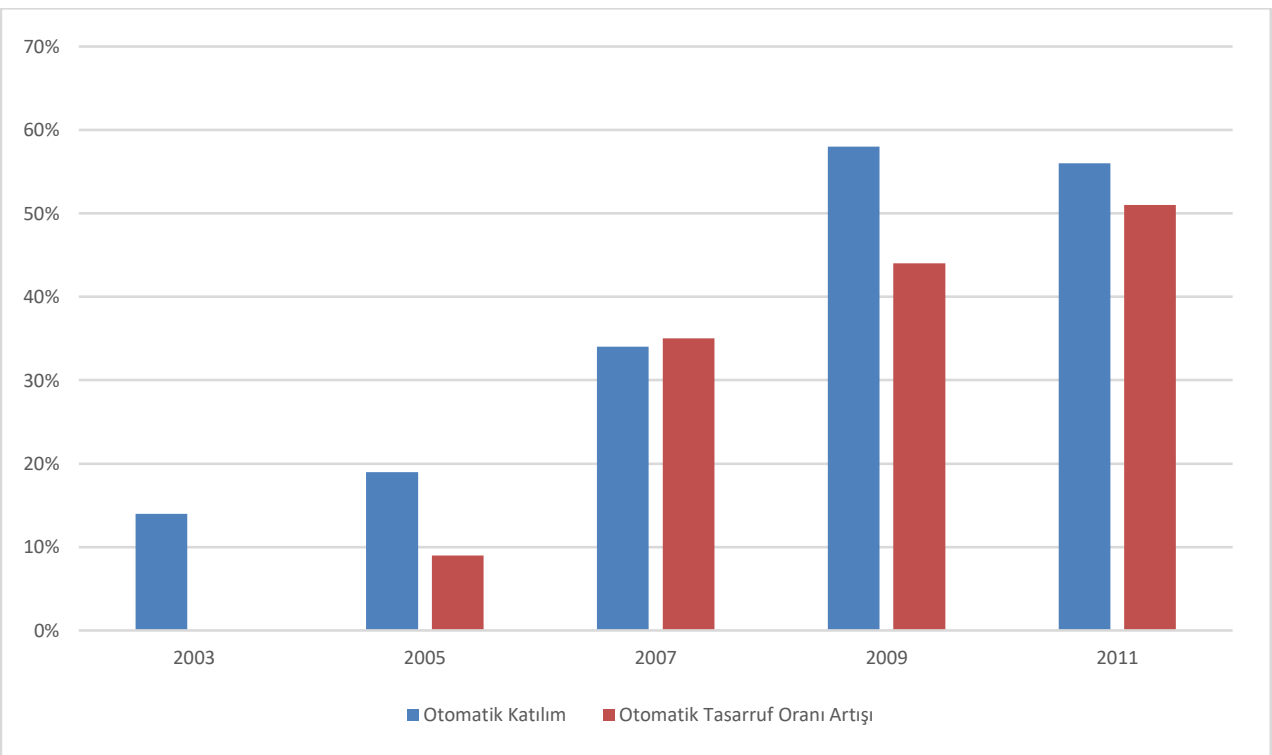

Kaynak: Benartzi \& Thaler, 2013.

Yukarıdaki grafikte, otomatik katılım ve tasarruf oranı artışının 8 sene içerisinde yaklaşık \%50 civarında arttığı görülmektedir. Dürtmenin yarattığı küçük etkinin büyük sonuçlar doğurması ve bu politikalar uygulanırken özgürlükçü paternalizm yaklaşımının benimsenmesi, politikaların etkinliğini arttırmaktadır. Özgürlükçü paternalizm bireyleri iyi seçeneğe yönlendirirken, diğer seçenekleri de tercih edebilmesini olanaklı kılmaktadır (Thaler \& Sunstein, 2003: 1161).

\section{Davranışsal İktisadın Epistemolojik ve Metodolojik Çerçevesi}

Bilimi anlamak, uzun yıllardır süregelen ve çeşitli yaklaşımların doğmasına yol açan derin bir serüvendir. Bu uzun süreçte, bilimsel farkındalık gelişirken çevresinde şekillenen disiplinlere yönelik farklı yaklaşımlar da doğmuştur. İlk olarak metafizik, ardından metafiziğin Auguste Comte'un katkılarıyla pozitivizme (Comte, 1896: 33) ve sonrasında Viyana Çevresi etkisiyle mantıksal pozitivizme evrilişi (Kulandina, 2017) tüm disiplinlerin 
değerlendirmesinde farklılık yarattığ 1 gibi iktisat disiplininde de görüş farklılıklarına yol açmıştır.

Mantıksal pozitivizm, bilimin felsefeden tamamen arındırıldığı, tikelden tümele ilerleyen, ampirizme ve hipotezlerin doğrulanmasına dayalı bir yaklaşımdır (Russell, 1949). Karl Popper ise, bu yaklaşımı doğrulanabilir hipotezlerin yorumlara açık olduğu görüşüyle eleştirmiş ve bilimin ancak yanlışlama yöntemiyle gerçekliğe kavuşacağ1 görüşünü savunmuştur. Bunun yanında, hipotezler reddedilebilmeli ve test edilebilmelidir (Popper, 1963: 1-2). Fakat, Popper'in görüşlerinde de eleştiriye açık noktalar vardır.

Popper'in yanlışlama yaklaşımında teori tek bir teste tabi olduğundan, herhangi bir hipotez veya varsayım reddedildiğinde teorinin reddedildiği varsayılmaktadır. Bu eleştiri Duhem-Quine tezi olarak bilinmektedir (Hesse, 1969). Kuhn ise, Popper'in yanlışlama yaklaşımının çeşitli ihtimalleri de barındırması gerektiğini ileri sürmektedir (Kuhn, 1995: 157-158). Bunun temel sebebi ise, geçmişte kabul edilen ve şu anda yanlışlanan bir teorinin varlığı mümkünse, bugün kabul edilen teorinin gelecekte yanlışlanabilecek olmasıdır. Kuhn'a göre, bilim tarihsel açıdan ele alınmalıdır (Kuhn, 1995: 46-47). Bilgi, üç aşamadan geçmektedir: Öngörü, normal bilim ve paradigma değişimi. İlk aşamada, olgular gözlemlenir ve değerlendirilir; ikinci aşamada paradigma oluşur ve paradigmaya olan inanç tamdır. Son aşamada ise, paradigma içerisinde meydana gelen krizler, paradigmanın değişmesine ya da kaymasına sebep olur (Dhami, 2016: 5).

Kuhn ve Popper'in görüşlerinin farklı noktalarından yararlanarak bilimsel araştırma programı adında yeni bir görüş ortaya atan Lakatos'a göre, paradigmada asla bozulmayan bir çekirdek ve onun çevresinde paradigmayı koruyan varsayımlar ve hipotezler bulunmaktadır. Yeni teorinin varsayımları eski varsayımların yerini alacak kadar deneysel ise, teorinin gerçekliği kabul edilir (Lakatos, 2014: 46).

Bilimsel metodolojideki farklı yaklaşımlar, iktisadın yorumlanmasında da farklılıklara yol açmıştır. Mantıksal pozitivizmin başat hale geldiği teoriler, Friedman (1966)' 'n görüşleriyle -sanki (as if) ve enstrumantalist yaklaşımları- gelişim göstermiş, Popper metoduyla harmanlanmış ve benimsenen görüş adı altında ana akım iktisatta hegemon olmuştur (Yay \& Yay, 2000: 15-16).

Benimsenen görüşün matematiksel ve ekonometrik modelleri destekleyen rasyonalite ve azami fayda varsayımları iktisatta farklı yaklaşımların eleştirilerinin odak noktası olmuş, yakın dönem davranışsal iktisat ise teorilerin revize edilmesi gerektiğini savunmuştur. Tomer (2007), davranışsal iktisadın ana akım teorilerden ayrılan noktalarını kısıtlılık, katılık, hoşgörüsüzlük, mekaniklik, ayrılık ve bireyselcilik olarak sınıflandırmıştır.

Davranışsal iktisadın epistemolojik çerçevesi irdelendiğinde, Popper ve Lakatos’a yakın olduğu, Kuhn'un görüşlerini desteklemediği sonucuna ulaşılabilir. Davranışsal iktisat ana akım teorilerin çekirdeğini değiştirmeden, yalnızca çevresindeki rasyonalite ve azami fayda gibi varsayımlarını yenileyerek paradigmayı revize etmektedir. $\mathrm{Bu}$ durumda, 
hipotezleri yanlışlama noktasında Popperci, çekirdeğe dokunmama noktasında ise Lakatoscu olarak addedilebilir. Kuhn'a göre bu noktada paradigma kayması veya değişimi söz konusu olmalıdır, fakat davranışsal iktisat uygulamalarında bu durum görülmemektedir.

Davranışsal iktisadın metodolojisi ele alındığında ise, araştırmalarda bilişsel deneylerin kullanıldığı görülmektedir. Davranışsal iktisatta bu uygulama Kahneman ve Tversky'nin çalışmalarıyla başlamıştır, fakat iktisattaki ilk deneysel uygulamalar davranışsal iktisat kapsamında gerçekleşmemiştir. Psikoloji ve iktisadın birlikte ele alındığı çalışmalara bakıldığında deneysel iktisatta da aynı metotların kullanıldığı görülmektedir. Davranışsal iktisat ve deneysel iktisat arasında ise bazı belirleyici özellik farklılıkları bulunmaktadır.

Deneysel iktisadın öncü isimlerinden biri olan Vernon L. Smith, ana akım iktisadın benimsenen görüş yaklaşımını eleştirmektedir (Bergstorm, 2003: 181). Benimsenen görüşe göre iktisadi olgular astroloji ve meteoroloji gibi gözlemlenebilirdir. Smith, iktisadın da fizik ve kimya gibi deneysel olması gerektiğini ve deneysel metodun iktisat için başat hale gelmesi gerektiğini savunmaktadır (Tomer, 2007: 475). Bu bağlamda deneysel iktisat demografik faktörleri, saha verilerini, kişisel raporları genellikle göz ardı etmektedir (Camerer \& Loewenstein, 2004: 8). Davranışsal iktisat ise eklektiktir, farklı bilim dallarıyla da uyum içerisinde çalışabilir ve farklı metotlarla geniş bir yelpazede araştırmalar gerçekleştirebilir.

Davranışsal iktisat metodolojik olarak çeşitli seçim deneylerini, saha araştırmalarını, saha verilerini ve nörolojiyi kullanmaktadır. İlk olarak araştırmalarda hipotetik seçim deneyleri kullanılmıştır. Bu deneyler katılımcıların davranışlarına seçim kümelerini hayal ederek karar vermeleri olarak tanımlanmaktadır (Slovic \& Lichtenstein, 1970: 4). Hipotetik olarak gerçekleştirilen deneylerin geçerliliği ise deneysel iktisatçıların eleştiri odağ olmuştur (Angner \& Loewenstein, 2006: 40). Ardından gerçek çıktıyla deneyler gerçekleştirilmeye başlanmıştır. Bu deneylerde katılımcılar seçimlerini para, kahve kupası, hediye çekleri aracılığıyla değerlendirmektedir. Zaman içerisinde hipotetik deneyler ile gerçek çıktılı deneylerin karşılaştırıldığı farklı bir literatür ortaya çıkmıştır. Bu tartışma sürerken, deneysel çalışmaların laboratuvarda gerçekleşmesi üzerine eleştiriler gelmiş ve deneylerin laboratuvar dışında da yapılması gerektiği fikri oluşmuştur. Bu tartışmanın ardından davranışsal iktisatçılar saha verilerini ve saha deneylerini de araştırmalarına dâhil etmişlerdir.

Deneylerin geçerliliği üzerine yapılan bir diğer tartışma ise içsel ve dışsal geçerlilik sorunudur. Bu sorun deneysel iktisatçıların ilgilendiği bir konu olmakla birlikte, davranışsal iktisatçılar içsel geçerliliği nedensel sonuçların güvenilebilirliği, dışsal geçerliliği ise çalışmanın bağlamından hedefe doğru genişlemesi olarak ele almaktadır (Loewenstein 1999: F26, Heukelom, 2009: 11-12).

Son olarak, nörolojik gelişmeler de davranışsal iktisadın metodolojisinde yer edinmeye başlamış, karar alma mekanizmasının altında yatan etkenler teorilere dâhil 
edilerek, kara kutu olarak tanımlanan beynin işleyiş mekanizması aydınlatılmaya başlanmıştır. Araştırmalar göz takibi, EEG, fMRI ve PET gibi yöntemlerle; zamanlar arası tercih, belirsizlik, doğrusal olmayan olasılık ağırlığı ve oyunlarda sınırlı stratejik düşünme gibi konuları incelemektedir (Camerer, 2007: C30-C32).

Davranışsal iktisadın epistemolojik ve metodolojik gelişimi daha detaylı olarak ele alınması gereken konulardır. Etkileşimde bulunduğu disiplinlerin ilerleyişiyle birlikte daha hızlı gelişen davranışsal iktisadın, gelecekte ana akım teorilerin eksikliklerini gidereceği öngörülmektedir (Thaler, 2016).

\section{Türkiye'de Davranışsal İktisat}

Davranışsal iktisat birçok ülkede gelişim gösterdiği gibi, Türkiye'de de gerek akademik gerekse politik çevrede ele alınmaya başlanmıştır. Davranışsal iktisat kapsamında kamu politikaları üretilebilmesi adına Ticaret Bakanlığı bünyesinde Davranışsal Aksiyon Takımı: Nudge Unit 2017 yılında kurulmuş ve çalışmalarına başlamıştır (Ticaret Bakanlığı, 2018). Öte yandan Bilgi Üniversitesi (BELİS), ODTÜ (BEL) ve İstanbul Üniversitesi (Davranışsal İktisat ve Tüketici Araştırmaları Merkezi)'nde deneysel laboratuvarlar kurulmuş ve akademik çalışmalar hız kazanmıştır.

Karabulut (2008) ve Neyse (2011), güven oyunu kapsamında Türkiye'deki iktisadi güven düzeyini analiz etmişlerdir. Karabulut (2008) Türkiye'deki güven oranını \%48 olarak tespit etmiştir. Bu durum, diğer ülkelerle kıyaslandığında güvenin düşük olduğu sonucunu göstermektedir. Neyse (2011) ise, sınıflandırma yaparak ölçtüğü güven düzeyini \%46 bularak Karabulut (2008)'i destekleyen bir sonuç elde etmiştir.

Türkmen vd., (2012), çerçeve etkisinin varlığını ispatlayan bir anket çalışması gerçekleştirmiş, Hatipoğlu (2012) ise 2008 küresel krizini davranışsal iktisat bağlamında değerlendirmiştir.

Kamilçelebi (2013), 247 bankacılık ve sigortacılık öğrencisinin katılımıyla yaptığ1 deneyde deneyimlenen fayda ve karar faydası arasındaki çelişkiyi tespit etmiştir. Öğrencilerin özel sektördeki iş bulma olasılığının fazla olması dolayısıyla bölümden hoşnut olması karar faydası, bir kamu kuruluşunda çalışma isteği ise deneyimlenen fayda olarak ele alınmıştır. Yapılan ankete göre deneyimlenen faydanın daha ön planda olduğu belirlenmiştir.

Akay vd., (2013), dini bayramlar ve dindarlığın pozisyonellik olarak tanımlanan karşılaştırma eğilimi üzerindeki etkisini incelemişlerdir. Katılımcıların tüketim ve gelir seviyelerini çevreleriyle karşılaştırdıklarını, bu durumun Ramazan ayında biraz daha az gerçekleştiğini bulgulamışlardır. Dumludağ vd. (2015) ise, gelir karşılaştırmasının yarattığ mutluluğun gelirdeki artışla yaşanan mutluluk kadar belirgin olduğu sonucuna ulaşmıştır. 
Tepeler (2017), emek sonucu ve emek harcanmadan elde edilen kazançların nasıl değerlendirildiği irdelenmiştir. İki grup arasında oynanan ültimatom oyunu sonucunda iki grubun tekliflerinin farklılaştığı bulgulanmıştır.

Türkiye'ye yönelik davranışsal iktisat literatürü incelendiğinde çalışmaların genellikle anket yoluyla yapıldığı görülmektedir. Bu çalışmaların teorik ve politik çerçeveyi destekleyebilmesi adına deneysel metotlarla gerçekleştirilmesi ve Türkiye'nin yapısal özellikleri kapsamında spesifik deneyler tasarlanması gerekmektedir.

\section{Sonuç}

Ana akım iktisadın Homo economicus varsayımına eleştiri niteliğinde gelişim gösteren davranışsal iktisat uzun yıllar boyunca farklı bilim dallarıyla etkileşim içerisinde ilerleme kat etmiş ve günümüzde her alanda etkin politikalar üretebilecek konuma ulaşmıştır.

$\mathrm{Bu}$ çalışmada, psikolojik olguların marjinal devrime kadar teorilere dahil edilmesi, marjinal devrimle birlikte iktisat disiplininin mantıksal pozitivizmi başat hale getirmesi, ardından bilişsel devrimle psikolojik olguların tekrar disipline dahil edilmesi ve son olarak bilişsel deneylerin gelişimiyle birlikte modern davranışsal iktisadın ortaya çıkış öyküsü ele alınmıştır. Bu uzun süreçte, davranışsal iktisadın erken dönem ve yakın dönemi arasındaki perspektif farkı, epistemolojik ve metodolojik arka planı değerlendirilmiştir.

Davranışsal iktisat araştırmacıları (Herbert Simon, Daniel Kahneman, George Akerlof ve Richard Thaler) Nobel ekonomi ödülüne sahip olmuşlar ve alanın önemi her geçen yıl daha da artmıştır. Çoğu ülkede dürtme kapsamında gerçekleşen ufak müdahaleleri politika yapıcılar da uygulamaya başlamışır.

Davranışsal iktisadın eklektik bir bilim dalı olması, farklı disiplinlerle iş birliği sağlayarak daha hızlı gelişim göstermesine olanak sağlamışır. Göreceli olarak yeni kabul edilebilecek bu disiplinin Türkiye'de de daha fazla konu edilmesi gerekmektedir. Türkiye'deki akademik çalışmalar incelendiğinde, alanın hala deneysel gelişim sürecinde olduğu görülmektedir. Bu çalışma, Türkiye'deki araştırmacılara ve kurumlara bir kaynak sağlamak ve Türkiye'de davranışsal iktisadın gelişiminin hızlandırılmasına yardımcı olmak amacıyla ele alınmıştır. Gelecekte, tüm iktisat disiplininin bu çerçeveyle gelişim gösterebileceği varsayıldığında, Türkiye'nin küresel anlamdaki ilerlemeye yetişebilmesi için çalışmaların hız kazanması önem arz etmektedir.

\section{Kaynaklar}

Akay, A. \& G. Karabulut \& P. Martinsson (2013), “The Effect of Religiosity and Religious Festivals on Positional Concerns - An Experimental Investigation of Ramadan", Applied Economics, 45(27), 3914-3921. 
Angner, E. \& G. Loewenstein (2006), Behavioral Economics, $\langle$ https://www.cmu.edu/dietrich/sds/docs/loewenstein/BehavioralEconomics.pdf $>$, 17.02.2018.

Ashraf, N. \& C.F. Colin \& G. Loewenstein (2005), “Adam Smith, Behavioral Economist”, Journal of Economic Perspectives, 19(3), 131-145.

Barberis, N. (2018), "Richard Thaler and the Rise of Behavioral Economics", Yale ICF Working Paper No. 2018-03, <https://ssrn.com/abstract=3111475>, 30.10.2018.

Benartzi, S. \& R. Thaler (2013), "Behavioral Economics and the Retirement Savings Crisis", Science, 339, 1152-1153.

Bentham, J. (1781), An Introduction to the Principles of Morals and Legislation, Kitchener: Batoche Books.

Berg, N. \& G. Gigerenzer (2010), “As-If Behavioral Economics: Neoclassical Economics in Disguise?", History of Economic Ideas, 18(1), 133-166.

Bergstrom, T.C. (2003), "Vernon Smith's Insomnia and the Dawn of Economics as Experimental Science", Scand. J. of Economics, 105(2), 181-205.

Boulakia, J.D.C. (1971), "Ibn Khaldûn: A Fourteenth-Century Economist”, Journal of Political Economy, 79(5), 1105-1118.

Camerer, C. \& G. Loewenstein (2004), "Behavioral Economics: Past, Present and Future", içinde: C. Camerer \& G. Loewenstein \& M. Rabin (eds.), Advances in Behavioral Economics, New York: Russell Sage Foundation, 3-42.

Camerer, C. \& S. Issacharoff \& G. Loewenstein \& T. O’Donoghue \& M. Rabin (2003), "Regulation for Conservatives: Behavioral Economics and the Case for 'Asymmetric Paternalism"”, University of Pennsylvania Law Review, 151(3), 1211-1254.

Camerer, C.F. (2007), "Neuroeconomics: Using Neuroscience to Make Economic Predictions", The Economic Journal, 117(519), C26-C42.

Comte, A. (2000), The Positive Philosophy of Auguste Comte, H. Martineu (Çev), Kitchener: Batoche Books.

Curtin, R. (1982), "Indicators of Consumer Behavior: The University of Michigan Surveys of Consumers", Public Opinion Quarterly, 46(3), 340-352.

Çetin, T. (2010), “İktisadi Etkinlik Üzerine Bir Deneme: X Etkinlik Yaklaşımı”, Doğuş Üniversitesi Dergisi, 11(2), 183-198.

Demir, Ö. (2013), Akıl ve Çıkar: Davranışsal İktisat Açısından Rasyonel Olmanın Rasyonelliği, 1. Bask1, Ankara: Sentez Yayınc1lık.

Dhami, S. (2016), The Foundations of Behavioral Economic Analysis, 1. Bask1, New York: Oxford University Press.

Dumludağ, D. \& E. Ruben (2015), “Davranışsal İktisadın Gelişimi”, İktisat ve Toplum, 58, 4-9.

Dumludağ, D. \& Ö. Gökdemir \& S. Giray (2015), "Income Comparison, Collectivism and Life Satisfaction in Turkey", Quality and Quantity, 50(3), 955-980.

Earl, P. (2005), "Behavioural Economics and the Economics of Regulation", Briefing paper prepared for the New Zealand Ministry of Economic Development.

Edgeworth, F.Y. (1881), Mathematical Phychics: An Essay on The Application of Mathematics to The Moral Sciences, Londra: C. Kegan Paul \& CO. 
Erkan, B. (2016), “Ana Akım (Ortodoks-Neoklasik) İktisat Öğretisi Eleştirisi: Heterodoks Yaklaşım İhtiyacı”, Akademik Araştırmalar ve Çalışmalar Dergisi, 8(14), 25-40.

Fisher, I. (1928), The Money Illusion, New York: The Vail-Ballou Press.

Fisher, I. (1930), Theory of Interest, New York: The MacMillan Company.

Friedman, M. (1966), “The Methodology of Positive Economics”, içinde: Essays in Positive Economics, Chicago: University of Chicago Press, 3-43.

Gardner, H. (1987), The Mind's New Science, New York: Basic Books.

Gierer, A. (2001), "Ibn Khaldun on Solidarity (“Asabiyah”) Modern Science on Cooperativeness and Empathy: a Comparison", Philosophia Naturalis, 38, 91-104.

Hastings, J. \& J.M. Shapiro (2018), "How Are SNAP Benefits Spent? Evidence from a Retail Panel", American Economic Review, 108(12), 3493-3540.

Hatipoğlu, Z. (2012), Davranışsal İktisat: Bilișsel Psikoloji ile Krizi Anlamak, <http://teacongress.org/papers2012/HATIPOGLU.pdf>, 04.12.2018.

Hesse, M. (1969), “Duhem, Quine and A New Empirıcism”, Royal Institute of Philosophy Supplements, 3, 191-209.

Heukelom, F. (2009), "Origin and Interpretation of Internal and External Validity in Economics", NiCE Working Paper, 09-111.

İbn Haldun (2013), Mukaddime, T. Dursun (Çev.), 1. Cilt. İstanbul: Kaynak Yayınları.

Juster, T.F. (2004), “The Behavioral Study of Economics”, içinde: A Telescope on Society: Survey Research and Social Science at the University of Michigan and Beyond, Michigan: University of Michigan Press, 119-194.

Kahneman, D. \& A. Tversky (1972), "Subjective Probability: A Judgment of Representativeness", Cognitive Psychology, 3, 430-454.

Kahneman, D. \& A. Tversky (1973), “On The Psychology of Prediction”, Psychological Review, 80(4), 237-251.

Kahneman, D. \& A. Tversky (1974), “Judgment under Uncertainty: Heuristics and Biases”, Science, $185,1124-1131$.

Kahneman, D. \& A. Tversky (1979), "Prospect Theory: An Analysis of Decision under Risk", Econometrica, 47(2), 263-291.

Kahneman, D. \& J.L. Knetsch \& R.H. Thaler (1990), "Experimental Tests of the Endowment Effect and the Coase Theorem", Journal of Political Economy, 98(6), 1325-1348.

Kahneman, D. \& J.L. Knetsch \& R.H. Thaler (1991), "The Endowment Effect, Loss Aversion, and Status Quo Bias", Journal of Economic Perspectives, 5(1), 193-206.

Kahneman, D. (2003), "Maps of Bounded Rationality: Psychology for Behavioral Economics", The American Economic Review, 93(5), 1449-1475.

Kahneman, D. (2011), Hızlı ve Yavaş Düşünme, O.Ç. Deniztekin \& F.N. Deniztekin (Çev.), 7. Bask1, İstanbul: Varlık Yayınları.

Kamilçelebi, H. (2013), "Davranışsal İktisatta Deneyimlenen Fayda ve Karar Faydası Arasındaki Fark ve Bir Deney”, Dokuz Eylül Üniversitesi Sosyal Bilimler Enstitüsü Dergisi, 15(3), 447-456.

Karabulut, G. (2008), “Türkiye'de İktisadi Güven: Uluslararası Bir Karşılaştırma”, Sosyal Bilimler Dergisi, 1, 123-128. 
Katona, G. (1951), "Psychological Analysis of Economic Behavior", New York: McGraw-Hill.

Kayapınar, A. (2006), “İbn Haldûn’un Asabiyet Kavramı: Siyaset Teorisinde Yeni Bir Açılım”, Íslâm Araştırmaları Dergisi, 15, 83-114.

Keynes, J.M. (1921), A Treatise On Probability, London: MacMillan.

Keynes, J.M. (1997), The General Theory of Employment, Interest and Money, New York: Prometheus Books.

Kozak, İ.E. (1984), İbn Haldun'a Göre İnsan-Toplum-İktisat, 1. Bask1, İstanbul: Pınar Yayınları.

Kuhn, T.S. (1995), Bilimsel Devrimlerin Yapısı, N. Kuyaş (Çev.), 4. Baskı, İstanbul: Alan Yayınc1lı.

Kulandina, Y. (2017), Viyana Çevresi: Metafiziğin Reddi ile Bilim Felsefesindeki 'Radikal' Dönüşüm, <https://dusunbil.com/viyana-cevresi-metafizigin-reddi-ile-bilimfelsefesindeki-radikal-donusum/>, 01.05.2019.

Laibson, D. \& J.A. List (2015), "Principles of (Behavioral) Economics", The American Economic Review, 105(5), 385-390.

Lakatos, I. (2014), Bilimsel Araştırma Programlarının Metodolojisi, D. Uygun (Çev.), 1. Bask1, İstanbul: Alfa Bilim.

Leibenstein, H. (1966), “Allocative Efficiency vs. 'X-Efficiency”, The American Economic Review, 56(3), 392-415.

Lichtenstein, S. \& P. Slovic (1970), "Reversals or Preference Between Bids and Choices' in Gambling Decisions", Oregon Research Institute: Research Bulletin, 10(7), 1-28.

Loewenstein, G. (1999), "Experimental Economics from the Vantagepoint of Behavioural Economics", The Economic Journal, 109, F25-F34.

Loewenstein, G. (2000), "Prefrences, Behavior and Welfare: Emotions in Economic Theory and Economic Behavior", The American Economic Review, 90(2), 426-432.

Manoogian III, J. (2016), <https://commons.wikimedia.org/wiki/File:The_Cognitive_Bias_Codex__180\%2B_biases,_designed_by_John_Manoogian_III_(jm3).png>, 18.12.2019.

Neyse, L. (2011), “Davranışsal İktisat Çerçevesinde Güven Kavramı”, Yayımlanmış Yüksek Lisans Tezi, İstanbul Üniversitesi, İstanbul.

Popper, K. (1963), Conjectures and Refutations: The Growth of Scientific Knowledge, London: Routledge \& Kegan Paul.

Russell, B. (1949), “Logical Positivism”, Actas del Primer Congreso Nacional de Filosofia, Lógica y Gnoseología, 4, 1205-1232.

Schmid, A.A. (2004), Conflict and Cooperation: Institutional and Behavioral Economics, 1. Bask1, UK: Blackwell Publishing.

Scitovsky, T. (1992/1976), The Joyless Economy: The Psychology of Human Satisfaction, Revised Edition, New York: Oxford University Press.

Shefrin, H.M. \& R. Thaler (1988), "The Behavioral Life-Cycle Hypothesis", Economic Inquiry, 26(4), 609-643.

Simon, H. (1955), “A Behavioral Model of Rational Choice”, The Quarterly Journal of Economics, 69(1), 99-118.

Simon, H.A. (1966), Administrative Behavior: A Study of Decision-Making Process in Administration Organizations, 2. Bask1, New York: The Free Press. 
Smith, A. (2018/1759), Ahlaki Duygular Kuramı, D. Kızılay (Çev.), 1. Baskı, İstanbul: Pinhan Yayıncilik.

Sunstein, C.R. \& R. Thaler (2003), "Libertarian Paternalism is not an Oxymoron", The University of Chicago Law Review, 70(4), 1159- 1202.

Tepeler, M.İ. (2017), "Davranışsal İktisat Bağlamında Karar Vericilerin Risk Davranışlarının Deneysel Analizi”, Yayımlanmış Yüksek Lisans Tezi, Erzurum Teknik Üniversitesi.

Thaler, R. \& S. Benartzi (2004), "Save More Tomorrow ${ }^{\text {TM}: ~ U s i n g ~ B e h a v i o r a l ~ E c o n o m i c s ~ t o ~ I n c r e a s e ~}$ Employee Saving", Journal of Political Economy, 112(1), 164-187.

Thaler, R. \& S. Rosen (1976), "The Value of Saving a Life: Evidence from the Labor Market", içinde: Household Production and Consumption, NBER, 265-302.

Thaler, R. (1980), "Toward A Positive Theory of Consumer Choice", Journal of Economic Behavior and Organization, 1, 39-60.

Thaler, R. (1999), "Mental Accounting Matters”, Journal of Behavioral Decision Making, 12, 183206.

Thaler, R.H. \& C.R. Sunstein (2015), Dürtme: Sağlık, Zenginlik ve Mutlulukla İlgili Kararları Uygulamak, E. Günsel (Çev.), 4. Baskı, İstanbul: Pegasus Yayınları.

Thaler, R.H. (1997), "Irving Fisher: Modern Behavioral Economist", The American Economic Review, 87(2), 439-441.

Thaler, R.H. (2015), Misbehaving, 1. Bask1, UK: Penguin Books.

Thaler, R.H. (2016), "Behavioral Economics: Past, Present and Future", American Economic Review, 106(7), 1577-1600.

Ticaret Bakanlığ1 (2018); <https://ticaret.gov.tr/duyurular/davranissal-kamu-politikalarinda-akademiile-buyuk-isbirligi-odtu-nudge-bootcamp>, 02.12.2018.

Tomer, J.F. (2007), "What is Behavioral Economics", The Journal of Socio-Economics, 36, 463-479.

Türkmen, N.C. \& S. Demir \& B. Akgül (2012), "Çerçeve Etkisi Uygulama Örneği: Rasyonel Bireye Eleştirel Bir Bakış”, Okan Üniversitesi Finansal Riskleri Araştırma ve Uygulama Merkezi Tartışma Notları, <https://www.okan.edu.tr/okfram/OKFRAM/RePEc/okn/makaleler/turkmen0002.pdf>, 04.12.2018.

Tversky, A. \& D. Kahneman (1971), "Belief in The Law of Small Numbers", Psychological Bulletin, 76(2), 105-110.

Tversky, A. \& D. Kahneman (1973), “Availability: A Heuristic for Judging Frequency and Probability", Cognitive Psychology, 5, 207-232.

Tversky, A. \& D. Kahneman (1981), "The Framing of Decisions and the Psychology of Choice", Science, 211, 453-458.

Warneryd, K-E. (1982), "The Life and Work of George Katona", Journal of Economic Psychology, 2, 1-32.

Yay, T. \& G.G. Yay (2000), İktisat Yazıları: Metodoloji-Düşünce-Politika, 1. Bask1, İstanbul: Beta Yayınlar1. 
Tablo: 2

Model Tahmin ve Seçim Sonuçları

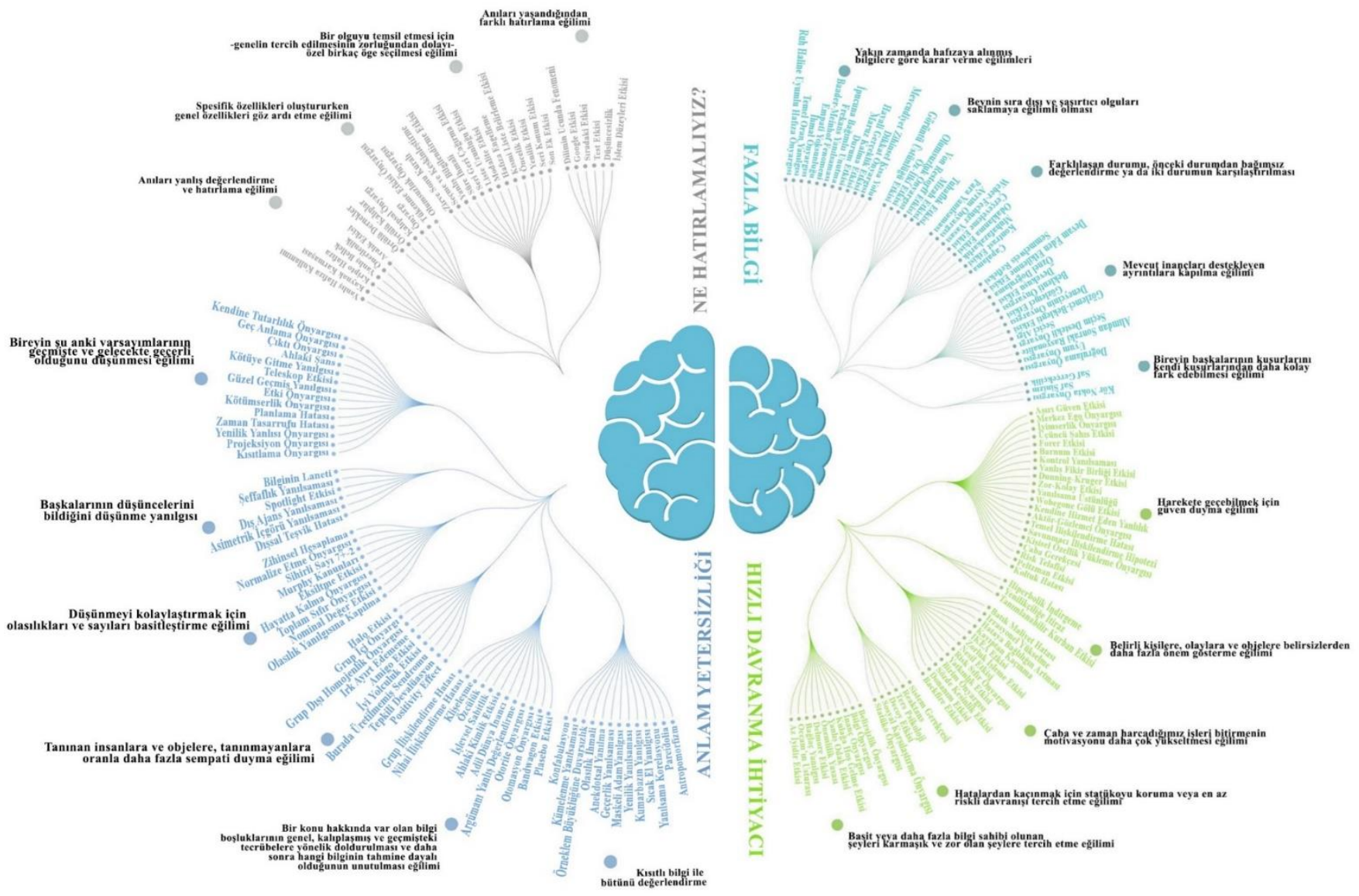

Not: Manoogian (2016)'dan Türkçeye uyarlanmıştır. 
Yücedoğru, R. \& S. Diraz (2021), "Davranışsal İktisadın Çerçevesi: Teorik, Epistemolojik ve Metodolojik Bir Bakıș”, Sosyoekonomi, 29(49), 323-343. 